\title{
Wedding Rituals on the Territory of Belarusian Palesse
}

\author{
Iryna Charniakevich \\ Department of Humanities \\ Hrodna State Medical University \\ Grodno, Belarus
}

\begin{abstract}
The article traces the local peculiarities of historical and ethnographic distribution of wedding rites in Belarusian Palesse. It is based on the analysis of a wide range of published sources, archival materials, and unpublished ethnographic field studies. This work was conducted in the context of Belarusian regional studies and concerns only the Belarusian part of Palesse, the territory which was subject to Belarusian ethnic processes in the early twentieth century and, in the second half of the twentieth century, was included in Belarusian territory; it does not apply to the entire region, that is Russian Poles'e, Ukrainian Polisse, and Polish Polesie. The analyzed rituals include all three stages of an East Slavic wedding ceremony: before the wedding, the wedding itself, and after the wedding. The common features and local differences of West and East Palesse weddings are discussed.
\end{abstract}

This article is a part of my research entitled "Historical and Ethnographic distribution of wedding rites in Belarusian Palesse." It is based on the analysis of a wide range of published sources, archival materials, and unpublished ethnographic field studies, including my own. Most of the sources used in this paper are from the first half of the twentieth century. However, taking into account the relative stability of traditional culture (at least prior to recent modernization) the use of published sources from the second half of the XIX century seems possible in a study like this.

It should be noted that this work was conducted in the context of Belarusian regional studies and concerns only the Belarusian part of Palesse, the territory which was subject to Belarusian ethnic processes in the early twentieth century and, in the second half of the twentieth century, was included in Belarusian territory; it does not apply to the entire region, that is Russian Poles'e, Ukrainian Polisse, and Polish Polesie. In academic literature the term Belarusian Palesse is now 
common. Researchers of traditional culture identify two historicalethnographic regions in Belarusian Palesse, namely East and West. Eastern Palesse occupies most of the Palesse lowland and, on the east, borders the Upper Dnieper region (the lower right bank of the Berezina River and Dnieper). Its northern border runs to the north from the town of Hantsevichy and along Parychy-L'uban'-Starobin-Chudzin line. According to V.S. Tsitou, the border between East and West Palesse runs from Lake Vyhanauskae and between the rivers Iasel'da and Bobryk toward the towns of Lahva, Luninets and further along the Prypiats' River and the rivers Haryn' and Stsviha. West Palesse occupies the upper basin of the Prypiats' River and its tributaries Pina and Iasel'da. In the west it includes the right bank of the Western Bug River, and in the north it borders the Upper Neman at the head water of the Narava and Iasel'da. [Tsitou 1994: 279, 286; Shamiakin 1989: 208, 507].

The East Slavic wedding ritual is divided into three stages: before the wedding, the wedding itself, and after the wedding. The Palesse variants of the first stage include two, three or even four meetings between representatives of the two families. The first meeting is called piarepyty (also perevid, zapytyny, dopyty); this is followed by matchmaking, called svatanne (also svaty, persha, zapoiny); then comes the viewing or ahledziny (also called rozhliady, obhodyny, merku zdymats', nastylnyky meraty); and last is the betrothal or zarychyny (also called zaruchenne, maharych, zmoviny, zapoiny). The stages piarepyty and ahledziny can vary according to region and are optional, while matchmaking and betrothal are obligatory and practiced in all regions; the two stages need not be separate events and can happen during one evening. The actual wedding begins with the baking of a loaf, the main ceremonial bread korovai. The other initial stage of the wedding is the evening for unmarried girls called vinky, vinochky, kvetki, byrachki, izbory, veliona shyts', or razbornaia kasha. The baking of the wedding bread can occur in both houses, meaning that of the bride and that of the groom, or it can be done in the groom's house only; in a few regions bread baking is absent. The evening for unmarried girls can be combined with baking a wedding bread in a bride's house; it is also possible not to hold an evening for unmarried girls at all. One of the most important moments in Palesse marriage is the pasad, or seating, of the bride. This is done before the arrival of the groom's friends (druzhyny) and it is sometimes combined with the baking of the wedding bread at the bride's house [Dovnar-Zapol'skii 1909: 97-106, 121-146; Baiburin 1993: 7074]. A variation of the pasad involves the friends of both the bride and 
groom, but takes place at the home of the bride's parents. Replacing the headdress that the bride wore as a girl with one which signifies married status is also an extremely important part of the wedding, but, in Palesse, does not occur at a specific point in the wedding. It could happen in the house of the bride's parents or it could take place after the wedding party moves to the house of the bridegroom. The next step is a ceremonial visit to the bride by members or representatives of her family which takes place at her husband's home on the morning after the wedding. This is called prydanyia, perazou, or perazva. Sometimes the bridegroom visits the in-laws ( $p a$ tsioshchu). This is followed by ritual masquerading which, in the Palesse wedding, has many variations. The final phase of the wedding is the first after-wedding visit by the bride to her parents' house. This is called hostyna, pirohi, or pyrohy [Bondarchik et al 1987: 167-172; Pashkova 1978; Shamiakin 1989: 126-131; Tsvirka 2004: 1529 and elsewhere].

According to Palesse tradition, the bride and groom at the wedding are called molodyi (molody) and molodia (moloda), all of which mean "the young". The name zhanikh (groom) is quite common in the contemporary recordings. This term has entered the lexicon as the result of the influence of the Russian language. The word niavesta (bride) in Palesse dialects meant "daughter-in-law" and it is rarely used to indicate the transitional state of a girl, meaning her status as a bride.

Palesse wedding rituals are characterized by a great deal of variation. This peculiarity has been identified by all investigators of Palesse culture and it causes difficulties when it comes to identifying the regional characteristics of traditional marriage. Because there is no stable structure to Palesse wedding rites, we find substantial differences in even the most important components and many of them are not fixed to a certain stage of the ritual [Gura 1981: 277]. Local traditions form a mosaic which is difficult to classify. However, some components of the wedding rite are typical for entire groups of variants. Upon determining the areas of distribution of these components, we can establish certain regularities. This leads us to assert that Palesse wedding ritual ceremonies do in fact have fairly stable complexes common to entire groups of local variants and that these complexes are distributed over a large territory. Analysis of local variants of marriage rituals in Belarusian Palesse shows that there are two stable complexes: the Eastern and the Western. 
East Palesse complex.

Traditionally, in this wedding complex, matchmaking took place without prior visits to the bride's family. As in other Eastern Slavic cultures, a Palesse girl had the nominal right to make the final decision and to agree or refuse to marry a particular man. However, she rarely exercised her right and she did not follow her personal desires if they did not coincide with the will of her parents and with public opinion. [Jeleńska 1891: 326]. East Palesse shows evidence of matrilocal marriages [AIMEF: fond 6, folder 3, unit 10, p. 10; Pashkova 1978: 30]. In such cases, the girl herself actively participated in the matchmaking. The girl's aunt or mother led the conversation with the mother of the groom-to-be. Such practices were observed in some Stolin region villages after World War II [Pashkova 1978: 84].

In other East Palesse weddings, a relative of the bridegroom performs the role of chief matchmaker; the groom's father is never allowed to act as matchmaker although his presence at this stage of the ritual is considered mandatory. As elsewhere in Palesse, the matchmakers speak in metaphors and absence of metaphorical speech is rare. Upon reaching an agreement between the families of the two young people, the girl's parents or she herself will invite all her kin to a celebration of the engagement that is called zapoiny or maharych. Such a celebration takes place one or two days after the agreement is made. The final verbal agreement, sealed by tying the relatives of the groom with a piece of linen or by the presentation of gifts, is concluded at the ceremony of betrothal. In the East Palesse wedding complex, the stages of matchmaking and engagement are quite flexible, and the terminology to describe these rites is completely different from that found in West Palesse.

One of the typical characteristics of the East Palesse wedding ceremony is the ritual of separation. The most common form of this ceremony is the making of a wedding tree (elka, velets, vilets, hil'tse) for one of the couple, usually for the bride. Wedding trees can be made for both the bride and the groom, in which case they are made separately. The making of the wedding tree for the bride usually happens at her home during the evening for unmarried girls, but it could also happen at the home of a relative. What is always true is that it needs to happen on the eve of the main wedding ceremony. The girl's wedding tree is then purchased or "ransomed" by representatives of the groom. In some areas, such as the village Kruki, Brahin district, the wedding tree is "ransomed" 
by the master of the house, meaning the father [AIMEF: fond 8 , folder 81 , unit 184 , fieldnotes 1, p. 9]. A description of the making of the wedding tree as practiced in the second half of XIX century in the village Dubrouka of Homel district, Mahileu huberniia written by E.R. Ramanau follows:

\begin{abstract}
"У той жа дзень [у дзень вянчання - I.Ч.] надвячоркам маладыя дзяўчаты клічуць адна адну: “Хадзіце елца віць!” Прыйшоўшы ў дом жаніха або нявесты, яны знаходзяць там кучаравую галінку вішні ці чарэшні або елку, утыкваюць у булку хлеба, які ставяць на стол. Старшая дзяўчына просіць благаславення, кажучы: “Ці ёсць тут ацец і маці?” Старыя адказваюць: “Маем быць!” - “Благаславіце маладому Івану елца завіць!” - “Божа благаславі!” Тады пачынаюць віць елку убіраць кветкамі. <..> Калі ўбяруць елку, дружок дае дзяўчатам за працу па чарцы гарэлкі".

[On the same evening, [the eve of the wedding - I.Ch.] young girls called to each other: "Come to make a tree!" Walking to the groom or bride's house, they would find a branch of a cherry tree or a fir tree, stick it into a loaf of bread, and put it on the table. The oldest girl would ask for blessing, saying: "Are the father and mother present?" The parents reply: "We are here!" "Bless young Ivan to curl the tree!" [The parents reply] "God bless!" After that they begin to "curl" the tree, that is to adorn it with flowers. $<\ldots>$ When the tree is ready, the best man gives each girl a glass of vodka to thank for her for a job well done.] [Tsvirka 2004: 406-407].
\end{abstract}

Making the wedding tree for the bride is associated with a change in a woman's status and the end of her participation in ritual groups comprised of unmarried girls. The ransoming of the tree together with the symbolic purchases made after the meal and the pasad are the regular features of East Palesse weddings.

The pasad as an indication of new status is important in both the East and West Palesse. Evidence of the existence of a pasad ceremony for a bridegroom in East Palesse at the turn of the century is recorded by A.S. Fiadosik in the materials based on folk traditions in the Loeu district. He states that "usually after the ceremony of bread baking, the groom, along with his best men, would go to the bride's home. In some villages, the groom went through the following ritual: he sat on a barrel of rye, while his godmother trimmed his hair and set it on fire with a wax candle. This indicated transition from youth to full manhood." [Fiadosik 2000: 556]. Accounts about the bridegroom's pasad on a barrel were also recorded in the village of Krasnaia Dubrova, Rechitsa district [Shteiner and Novak 2002: 179]. Usually, however, the groom did not go through a pasad and the ritual actions associated with him were limited to his being blessed by his parents "to go on a long journey." 
M. Dovnar-Zapol'ski identified three steps to the pasad ritual of the bride: cutting off or unplaiting her braids (pastryhanne or raspliatanne kasy), seating her on a sheepskin coat turned inside out, and the covering of her head. [Dovnar-Zapol'ski 1909: 121]. These ceremonies existed until almost the middle of the twentieth century and all three major structural components of this ritual were typically present. Ritual actions that placed restrictions on both participants in the wedding or rituals that required behaviors that were difficult to achieve, such as maintaining the chastity of both the bride and the groom, tended to disappear. What typifies East Palesse is that all three of components of the pasad survived into the present. Moreover, in the East, all the parts of the ritual were performed in the home of the bride's parents, including dressing the bride in the headdress of a married woman. This last ceremony was called "curling" (zavivanne) and was performed by specially designated female participants of the wedding called zavival'nitsy (zavival'nitsa sing.). The persons who assumed the role of zavival'nitsy were the female matchmakers (svakhi; svakha - sing.) from both sides, the bride's and the groom's, and they had to be happily married women. [Ritual Folklore 1998: 18 19, 30, 68, 76, 83, 90, 96; AIMEF: fond 7, folder 1, unit 879 , p. 36a; fond 8, folder 81, unit 182: 1, p. 44: 3, p. 39; Kryvitski et al 1987: 398]. The description of "curling" from E.R. Ramanau's records follows:

“...дзве маладзіцы становяцца на ўслон: адна трымае ў руцэ грабянец, другая - чапец, намітку і вялікі кавалак белага палатна. Каля іх ставяць хлопчыка - брата нявесты, які гаворыць: “Ці ёсць тут ацец і маці? Благаславіце маладой касу расплесці!” Хлопчык расплятае касу, бярэ сабе шнурок у паўтара аршына, а дружок дае яму некалькі капеек. Потым маладыя жанчыны пачынаюць завіваць маладой валасы пажаночаму: надзяваюць на галаву чапец і накрываюць наміткай. Маладая ўсё гэта скідвае 3 галавы некалькі разоў, пакуль ёй не прыгрозіць бацька. Завіўшы маладую, маладзіцы спяваюць: "Шчо мы і схацелі, // Тое і зрабілі: // 3 цеста паляніцу, // 3 дзеўкі маладзіцу”.

[... two girls stand together, one holding a comb, the other a cap (chapets), a head wrap (namitka) and a large piece of white linen. A young boy, typically the bride's brother, stands with them. He says: "Are Father and Mother present? Bless the bride so that we may unplait her braid!" The boy then unplaits the braid and, as his reward, he takes a string about a half a yard in length and the best man gives him a few pennies. Then the zavival'nitsy begin to "curl" (zavivats') the bride' hair in a new way suitable for her new status. They put the cap on her head and cover it with the headwrap. The bride takes the new headdress off of her head several times, until her father threatens her. After the curling, the zavival'nitsy sing: "We did what we wanted to do, / We made bread out of dough / We made a woman out of a girl] [Tsvirka 2004: 411].

FOLKLORICA 2011, Vol. XVI 
The wedding ceremonies associated with bread (karavainyia abrady) are relatively poorly attested in East Palesse as indicated by the well-known scholar of the folklore of the Homel' district V.S. Novak [Novak 1998: 355]. However, there are distinctive features associated with the baking of the karavai. These include the decoration of the wedding bread (karavai) and, occasionally of the wedding tree, made by bridesmaids [AIMEF: fond 8, folder 81, unit 182: 1, p. 39; Shteiner and Novak 2002: 160-161]. There are no records that indicate that decorations made of tree branches and used exclusively for the karavai were made in conjunction with East Palesse weddings. Rather, a distinctive feature associated with the karavai is its distribution among the wedding guests as part of the gift-giving ceremony. [Ritual Folklore 1998: 20-21, 76, 93, 96; AIMEF: fond 8, folder 81, unit 184: 3, p. 43, folder 83, unit 210: 3, p. 87; Tsvirka 2004: 550; Shteiner and Novak 2002: 162, 207].

A common feature of the East Palesse wedding is the presence of games with erotic content called khvasty (tails) or zaiats (rabbit). A variant of the erotic games is the mock wedding. All variants occur in the final stages of the wedding and include the act of eating chicken or other meat cooked in a special way. The latter action could be included as a part of the mock wedding but is often a separate rite and could occasionally take up the entire day. [Ritual Folklore 1998, 31; 78; 8384]. A description by one of the informants from the village Slabazhanka, Khoiniki district follows:

"Пасля заканчэння вяселля ў маладой (з рукі маладога), і ў маладога (3 рукі маладой) гуляюць у “зайца". За маладую адзяваюць "шутлівую” жанчыну і мужчыну - за маладога. Надзяваюць вянок, зроблены 3 палявых красак, прышываюць замест кветкі розгу з веніка, замест свечкі - дзяркач дзіравы. Садзяць іх на куце, зводзяць іх і цалавацца, як i маладых, у сажу вымазваюць. Даруць: гарбузы выражуць, падмазку, што скавараду мажуць - гэта пудраніца, засланку - гэта люстра. Скруцяць ляльку 3 трапак - гэта ты бярэш жонку 3 прыданым байбуком. Выходзяць на вуліцу і крычаць: "Паймаем зайца, паймаем". Адзін бярэ стрэльбу і страляе, заяц падае: ці “малады”, ці “маладая”. А тады ўжо прыходзяць да лупяць таго зайца. Ужо ложаць на стол ратаваць зайца. Стараюцца падвесці мужчыну, які не ведае гэтага звычаю. А зайцу даюць гарэлкі ў рот, ён дзяржыць. Як толькі падыходзіць хто “ратаваць", то заяц прысне яму ў твар, вочы гэтаю гарэлкаю. Потым зноў ідуць у хату - гэта ж убілі зайца, трэба замачыць. У панядзелак, пасля заканчэння вяселля адны свахі гатуюць ежу, прадукты к гэтаму зайцу, а другія пераапранаюцца ў цыганскае адзенне, бяруць маскі (капронавыя шкарпэткі, каб не пазналі), сумкі, кашы 
бяруць, ідуць па хатах. Людзі дараць, кур ловяць. Усё гэта сцягаецца на вясельны двор".

[After the wedding the game called "rabbit" is played at the home of the bride and also the groom. A young girl is dressed as a false or mock bride and a young man is dressed as a mock bridegroom. The girl wears a wreath made of weeds and the man wears broom bristles instead of the groom's flower; a rusty oven spade serves as a candle. The fake couple sits in the corner while the villagers make them kiss each other as if they were newlyweds and smear them with soot. The fake newlyweds receive humorous gifts such as a broken oven door or cover, a rag used to smear a pan with fat, and so forth. The presenters of the gifts claim that the rag is makeup and that the oven door that they present to the couple is a mirror. The villagers also make a rag-doll and claim that the groom is taking a wife with a "dowry," meaning one who is already pregnant. Also they go out on the street and yell: "We are going to catch a rabbit!" One of them then takes a gun and shoots; the "rabbit," and either the fake bride or the fake groom falls down. After that they start to prepare the "rabbit" and then put it on the table. Then they say they want to save the "rabbit". People try to find a man who does not know this custom. Meanwhile the "rabbit" is given vodka to hold in his (or her) mouth. As soon as the man chosen to "save" the "rabbit" approaches, the "rabbit" squirts vodka into his face and eyes. Then everyone goes into the house; the "rabbit" is "killed" and everyone is obliged to drink vodka (zamachyts"). On Monday, after the wedding, some of the wedding party cook food for this "rabbit"; while others dress in gypsy costume, put on the masks, usually nylon stockings pulled over the head so that they will not be recognized. They take bags and baskets and go around the village from house to house. The villagers give them presents; they even catch chickens. All this food is brought to the wedding house and consumed] [AIMEF, fond 8 , folder 81 , unit 184: 2, pp. 79-81].

As far as the official part of the wedding or civil registration of marriage is concerned, the population treats it mostly as a mandatory procedure. They do not, however, include it in the wedding ritual. Official registrations are performed before the traditional folk wedding and sometimes could occur after it [AIMEF: fond 6, folder. 3, unit 10, p. 25 , fond 7 , folder 1 , unit 879 , p. 36 , fond 8 , folder 83 , unit $211: 3$, p. 14 , unit 210: 3, p. 18; Tsvirka 2004: 540; Shein 1902: 400-401; Moszyński 1928: 183, 195, 200-201]. This is not the case with the religious or church part of the wedding. This is included in the wedding rite and typically occurs prior to the "curling" of the wedding tree. [Ritual Folklore 1998: 68; AIMEF, fond 8, folder 81, unit 184: 2, p. 23; Tsvirka 2004: 406].

The distinctive feature of the East Palesse wedding is the invitation of guests who include the groom's closest kin and the groom's new relatives, meaning the bride's kin, to feasts at the groom's house. These feasts are called biasedy, peravodziny, perazovy or piarezvy [Ritual 
Folklore 1998: 21; AIMEF: fond 7, folder 1, unit 879, pp. 25, 36, fond 8, folder 81, unit 182: 1, p. 46, folder 83, unit 211: 3, p. 54; unit. 210: 3, p. 87; Tsvirka 2004: 549; Pashkova 1978: 76; Shteiner and Novak 2002: 179]. In addition to helping distribute the expense of the wedding between the two families, such feasts serve as additional means of rapprochement between the new relatives-in-law.

On the morning of the nuptial night, the groom thanks his in-laws, and especially the bride's mother, who comes to visit her daughter in her new home. At this stage, the representatives of the bride are called prydannyia [Ritual Folklore 1998: 60, 76; AIMEF, fond 7, folder 1, unit 879 , p. 25 , fond 8 , folder 83 , unit $211: 3$, p. 16 , unit 210: 3 , p. 85 ; Tsvirka 2004: 548; MPAA, Zhytkavichy expedition 1999, notes 1, p. 27; Kryvitski et al 1987: 402]. This ritual serves to mark them as in-laws and relatives. After a while they change their clothes and start bridal games, which are a contest of sorts between the two families. In the East Palesse wedding such games typically have a clearly expressed erotic element. The most widespread games of such type are again mock weddings and include cross-dressing and various disguises such as donning gypsy dress; dressing as other characters and personages is also common [Ritual Folklore 1998: 8, 22, 29, 92; Kabashnikau 1998: 411; Shteiner and Novak 2002: 183, 201].

West Palesse complex.

This particular wedding complex can be further subdivided into central and western variants or subtypes. The basis for this division rests on cultural and economic relations, as well as on the pace with which traditional rural culture has been transformed.

In the villages of the Pinsk, Stolin, and Kobrin districts we find extensive attestation of a custom where, before matchmaking, the mother of the groom or another member of his female kin went to the perevid or perevidki at the home of the bride [MPAA, records by V.R. Shvaiko, 2000, Pinsk and Stolin regions, fieldnotes 1, pp. 1, 7, 17, 26; MPAZh, records from village Aniskavichy, Kobrin district, 1996, fieldnotes 1, p. 17, 4, p. 2; Zakharava 1984: 21; Pashkova 1978: 29, 84]. The purpose of this custom was to ascertain the intentions of the prospective bride's family. In the twentieth century this custom tended to lose its importance and disappear due to an increase in the number of marriages where the couple had reached a decision to marry on their own. 
After the exchange of breads which typically concluded the prematchmaking or perevid, matchmakers could be sent. The role of chief matchmaker was usually performed by the godfather of the groom, although the father also sometimes acted as matchmaker [Bandarchyk 1988: 17; Pashkova 1978: 31]. In the first half of the twentieth century, matchmaking was often held together with the zapoiny, although the rituals could also be performed separately. Apparently material circumstances and the presence or absence of a preliminary agreement between the families determined whether there would be a single ritual or two separate ones. Local tradition also determined whether the rituals were held together or separately. Thus, all respondents from of one of the villages where the author conducted fieldwork answered that matchmaking and zapoiny could happen on the same evening, as well as separately [MBrDU, Ivanava-Pinsk expedition 2000, fieldnotes 1, pp. 15, 22, 37; MPAA, Zhytkavichy expedition 1999, fieldnotes 1, p. 1; Drahichyn expedition 2000, fieldnotes 1, pp. 7, 9, 42].

In West Palesse we also find the custom of ahledziny during which the bride's parents examine the household and economic standing of the groom's parents [AIMEF, fond 7, folder 1, unit 879, p. 32; MBrDU, Ivanava-Pinsk expedition 2000, fieldnotes 1, pp. 6, 22; Stolin expedition 1997, fieldnotes 8, p. 1; MPAA, Zhytkavichy expedition 1999, fieldnotes 1, p. 1; Drahichyn expedition 2000, fieldnotes 1, p. 1; recordings by V.R. Shvaiko from 2000; fieldnotes 1, p. 2; MPAZh, recordings in the village Aniskavichy, Kobrin district from 1996, fieldnotes 4, p. 2]. The results of this examination could affect all stages of the upcoming wedding from start to finish and could even cause the cancellation of the wedding if the impression created during the ahledziny was negative (villages Vul'ka Antopalskaia, Drahichyn district; Kazhan-Haradok, Luninets district) [AIMEF, fond 7, folder 1, unit 879, p. 32; MPAA, Drahichyn expedition 2000, fieldnotes 1, p. 1].

An important feature of the West Palesse wedding is the form taken by the rites of separation which occur as part of the evening for unmarried girls and the pasad. The bride's passage from unmarried status to womanhood takes the form of the purchase or ransom (vykup) of the wedding wreath, the purchase of the bride's dress, the purchase of bride herself, or the purchase of a place next to the bride so that the groom could sit with her at the wedding banquet.

In West Palesse, the evening for unmarried girls is celebrated on a much grander scale than in the East. It is called vianki, vinky, or vinochny (wreaths). [AIMEF, fond 7, folder 1, units 879, p. 20; MBrDU, Zhabinka 
expedition 1996, fieldnotes 2, pp. 6, 15, 19; Brest expedition 1997, fieldnotes 1, pp. 13, 31; MPAA, records from 2003, fieldnotes p. 1; MPAZh, recording from the village of Aniskavichy, Kobrin district in 1996, fieldnotes 4, pp. 2-5]. Normally it takes place on Saturday, on the eve of the wedding. The bride, together with her bridesmaid, gathers all the girls who would attend the wedding in one place. The atmosphere of the evening is festive and the girls sing special songs and prepare flowers for the matchmakers to wear on their lapels; they also make a wedding headdress for the bride. The headdress is purchased by the bride or by her father on the same evening. Sometimes this is done by the groom, in which case he attends the ritual of vianki. The festivities continue late into the night and musicians are often invited. The ceremony of vianki in West Belarusian Palesse has survived into the present and the author herself has participated in such rituals in the early 1990s in Brest and the village of Hershony, Brest district.

In the central area of West Palesse, the rites of separation do not have a uniform character. The night for unmarried girls, which is called the vianki or vianochki is not celebrated in all villages [AIMEF, fond 7, folder 1, unit 879: pp. 31a, 49; MBrDU, Ivanava expedition 1996, fieldnotes 4, pp. 3, 22, 31; MPAA, Drahichyn expedition 2000, fieldnotes 1, pp. 10, 15, 40a; Klimchuk 1985: 270-274; Zakharava 1984: 256]. For kvetki (flowers) see [MBrDU, Ivanava expedition 1996, fieldnotes 4, pp. 3, 22]. For veliona shyts' (the imperative to sew) see [MBrDU, Ivanava-Pinsk expedition 2000, fieldnotes pp. 7, 23; MPAA, Drahichyn expedition 2000, fieldnotes, 1, p. 36]. For zbornaia subota (communal Saturday) see [AIMEF, fond 7, folder 1, unit 879: p. 31a]. For vyrachki (ransoming) see [MPAA, Drahichyn expedition 2000, fieldnotes 1, p. 32]. Respondents stated that the evening for unmarried girls is combined with baking of the karavai in the bride's home [MPAA, Zhytkavichy expedition 1999, fieldnotes 1, pp. 3, 6, 13, 24, 43; records from 2003, fieldnotes 2, p. 4]. Sometimes this ritual is not performed at all, especially in those villages where the preparation of the karavai is not part of the wedding ceremony. However, even in such cases, people still prepare a special headdress for the bride. This headdress is made by the bridesmaid on the night before the marriage or on the wedding day itself [AIMEF, fond 6, folder3, unit 10, p. 35; MPAA, records of V.R. Shvaiko from 2000, fieldnotes 1, pp. 3, 9, 18; Kryvitski et al 1984: 306].

Baking the karavai in the West Palesse wedding is a solemn event with an elaborate structure. The emphasis is the preparation of a karavai for the groom. In some locals, the karavai is baked only in the house of 
the groom [AIMEF, fond 8, folder 85, unit 230: 1, pp. 18-24; MBrDU, Stolin expedition 2001, fieldnotes 1, p. 12, Stolin expedition 1997, fieldnotes 8, p. 1; Ivanava expedition 1996, fieldnotes 4, pp. 3, 31; MPAZH, records from the village Aniskavichy of Kobrin district from 1996, fieldnotes 1, p. 17; Zakharava 1984: 53]. There are also local traditions where no karavai is baked. The absence of the ritual of the baking wedding bread is attested in several villages on the border of the Kobrin and Drahichyn districts (the village of Pavitstste, Kobrin district and the village of Radastava, Drahichyn district) [Pashkova 1978: 45]. The second group of villages where there are no ceremonies associated with the baking of a wedding bread are located on the border of the Pinsk and Stolin districts of Brest province (the villages of Kalavuravichy of the Pinsk district and Hal'tsy, Sitsitsk, Plotnitsa of the Stolin district) [MPAA, records by V.R. Shvaiko from 2000, fieldnotes 1, pp. 3, 9, 18, 26]. Interestingly, the local explanation for the lack of rites associated with the baking of the karavai is that it is not part of Ukrainian culture [MPAA, records by V.R. Shvaiko from 2000, fieldnotes 1, pp. 3, 9, 18, 26].

One of the distinctive features of the karavai ritual in the central area of West Palesse is the practice of decorating the wedding loaf with a "garden" (sad) and "pine cones" (shyshki). The karavai is decorated with tree branches, usually those taken from a fruit tree. These are cleaned and covered with dough. T.V. Tsiv'ian believes that Palesse folkloric material indicates a connection between the karavai and a garden. He concludes that an "imitation or symbolic garden" represents fertility and is thus connected with the wedding. The karavai in and of itself works as both a literal and a figurative representation of a garden and the conditions for its successful growth [Tsiv'ian 1983: 98]. In the same paper, this scholar links another wedding custom to the decoration of the karavai, or kviachennia: after the karavainitsy, the women who bake the ritual bread, have finished their task they wash their hands and pour the water out into the garden [AIMEF, fond 8, folder 83, unit 210, fieldnotes 32, p. 12; MBrDU, Ivanava-Pinsk expedition 2000, fieldnotes 1, pp. 2, 6; MPAA, Zhytkavichy expedition 1999, fieldnotes 1, pp. 1, 3, 13, 14, 34; Drahichyn expedition 2000, fieldnotes 1, p. 2; Zakharava 1984: 259; Kryvitski et al 1984: 309].

In the areas that are next to East Palesse, as well as in the western areas of West Palesse, the karavai is decorated more simply. The decorations are made out of the same dough as the karavai itself and applied before baking. The decorations added after the karavai is baked 
are limited to flowers; tree branches are not used. [Gura et al 1985: 5253; MPAA, Zhytkavichy expedition 1999, fieldnotes 1, pp. 26, 40, 51, 54].

Up until the point when the wedding bread is "purchased" from the women who had baked it, meaning the karavainitsy, and given to the father or senior matchmaker, young men who are participating in the wedding can steal it. They can also steal the shovel that was used to put the ritual bread into the oven. If they succeed in doing this, the money intended for women who made the bread is used to pay off the young men and ransom the karavai. This happens rarely, however, and there is a special song that is used to tease the men who might try to steal the bread: / / Наші хлопцы сморкачі, //Коровай наш вжэ в пэчі (Our lads are losers, // The bread is already in the oven).

In the central regions of Belarusian Palesse it is common to dress the bride in her wedding clothes while she is seated on the trough (dziazha) used to mix the karavai. If the bride is a virgin, the dziazha is covered with a sheepskin coat and she sits on top of this while the female members of the wedding help her dress [AIMEF, fond 7 folder 1, unit 879, pp. 33-34, 45; Tsvirka 2004: 541; MBrDU, Ivanava-Pinsk expedition 2000, fieldnotes 1, pp. 7, 23, 30; Ivanava expedition 1996, fieldnotes 5, p. 12; 91, pp. 37, 40; MPAA, Drahichyn expedition 2000, fieldnotes 1, pp. 7, 15, 19, 16, 24, 36, 47; Zakharava 1984: 264]. Bringing the bride and groom together for the ceremony of the pasad occurs first in the bride's house and is then repeated in the groom's home just after the arrival of the newlyweds.

In the western parts, the pasad as a ritual marking the new status of the newlyweds lost many of its features relatively early. Accordingly, respondents focus only on the fact that the bride and groom must sit together at the bride's home right after the church wedding. Thus the moment of bringing the future couple together is the most important component of the wedding for them; they do not describe an actual pasad ceremony.

In cases with a limited pasad ceremony, there was no ritual of the putting on the headdress which signifies the married status of the bride, a ritual that normally happens in the groom's house and could be an independent rite [AIMEF, fond 6, folder 3, unit 10, p. 35, p. 7, folder 1, unit 879 , pp. 20, 45, 50; MBrDU, Stolin expedition 2001, fieldnotes 1, pp. 2, 3, 9, 14, 17, 25, 32, 37; Ivanava expedition 1996, fieldnotes 4, pp. 5, 35; fieldnotes 5, p. 13; fieldnotes 7, p. 9; Zhabinka expedition 1996, fieldnotes 2, p. 8; MPAA, Zhytkavichy expedition 1999, fieldnotes 1, pp. 
4, 9, 13, 21, 23, 32, 34, 42, 49; Drahichyn expedition 2000, fieldnotes 1, pp. $5,18,21,24,34,40$; records from 2003 , fieldnotes 2 , p. 2 ; fieldnotes 1, p. 6, records by V.R. Shvaiko from 2000, fieldnotes 1, pp. 14, 22; MPAZh, records from 1996, village of Aniskavichy, Kobrin district, fieldnotes 4, p. 14; Zakharava 1984: 276; Pashkova 1978: 61]. In the West Palesse wedding there is a colorful contest between the wedding participants from the groom's side (called svatstse, baiary) and the wedding participants who are the bride's kin or come from her side. The conflict which takes place occurs when the bride is taken from her house of birth, and is much more pronounced than anything comparable in East Palesse weddings. This peculiarity can be attributed to the fact that, in this area, moving the wedding party to the home of the groom occurs early in the wedding ceremony and that the greater part of wedding ritual still remains to be performed. Correspondingly, placing the new headdress, the one that marks married status, on the bride's head (akruchvannia) takes place at the home of the groom.

The custom of "covering" the bride with a piece of fabric before she leaves to go to the home of her groom is also significantly elaborated and sometimes the bride's mother would cover both newlyweds with one namitka [head wrap] before they left. This namitka is later removed at the groom's home by his mother, his father, the best man (druzhko, halouny svat), or his godfather. This ceremony is called uskryvats' maladuiu, literally "to uncover the bride."

Giving presents to the newlyweds during the wedding happens at several stages. The newly wedded bride and groom are given the presents separately, that is the bride's kin offer gifts on their territory, meaning at the brides' home, and the groom's kin offer presents at his house. Of course exceptions are also possible [MBrDU, Stolin expedition 1997, fieldnotes 1, p. 3; MPAA, Zhytkavichy expedition 1999, fieldnotes 1, pp. 12, 35; Kryvitski et al 1985: 360]. At the time when research for this project was conducted, there were no instances in West Palesse where the giving of gifts was combined with the rite of dividing the karavai.

In some variants common to western areas of Belarusian Palesse, the so-called syrny abrad or cheese ceremony, is attested. The Ukrainian researchers V. Davydiuk and Z. Davydiuk give special attention to this rite [Davydiuk V. 1997: 7; Davydiuk Z. 1997: 239-241]. As recorded in the Brest region, the godmother of the bridegroom brings cheese as a treat for the pastaronniia baby (outside women), neighbors who do not participate at the wedding. In descriptions of this ceremony, special 
syrnyia (cheese) songs that accompany the rite are mentioned. [MBrDU, Brest expedition 1997, fieldnotes 1, pp. 3-4, 24].

An important stage of the wedding is the visit of the bride's relatives to the groom's house. In western regions (the villages of Brest, Zhabinka, and Kobrin districts), this step is usually called piarezvy [AIMEF, fond 7, folder 1, unit 879, p. 26; MBrDU, Zhabinka expedition 1996, fieldnotes 2, p. 8; Brest expedition 1997, fieldnotes 1, pp. 3, 16; MPAA, recordings from 2003, fieldnotes 1, p. 2; MPAZh, recordings from the village of Aniskavichy, Kobrin district made in 1996, fieldnotes 4, p. 12]. In eastern areas the name used for this rite is piarezv (see the villages of the Drahichyn and Ivanava districts, also some villages of the Pinsk and Zhytkavichy districts) [AIMEF, fond 7, folder 1, unit 879, pp. 35, 46, 50; MBrDU, Ivanava-Pinsk expedition 2000 fieldnotes 1, pp. 2, 10, 13, 15; Ivanava expedition 1996, fieldnotes 4, pp. 5, 16, 36, fieldnotes 5, pp. 14, 20, fieldnotes 7, p. 3; MPAA, Zhytkavichy expedition 1999, fieldnotes 1, p. 50, 54, Drahichyn expedition 2000, fieldnotes 1, pp. 8, 14, 17, 31, 40, 41; Zakharava 1984: 278-280]. In several villages of the Pinsk, Stolin, and Zhytkovichy districts and on the outskirts of the Starobin and Salihorsk districts the name prydanyiia is also attested [MBrDU, Stolin expedition 2001, fieldnotes 1, p. 12; Stolin expedition 1997, fieldnotes 1, p. 8, fieldnotes 8, p. 1; MPAA, Zhytkavichy expedition 1999, fieldnotes 1, pp. 8, 13, 15, 23, 29, 38; recordings from 2003, fieldnotes 2, p. 8; recordings by V.R Shvaiko from 2000, fieldnotes 1, pp. 15, 21, 26; Kryvitski et al 1987: 403]. In the village Kazhan-Haradok, respondents call this stage "breakfast for the newlyweds," (snedanne u maladoha) and the female participants of this breakfast are called snedal'nitsy [MBrDU, Luninets expedition 2004, fieldnotes 1, pp. 7, 13; MPAA, Drahichyn expedition 2000, fieldnotes 1, p. 5].

In in many villages of the Zhytkavichy and Stolin districts, there is a custom of bringing out the dough trough (dziazha) when the groom's parents come out to meet the bride. If she is a virgin, she is supposed to step on the trough. This custom existed till recently [AIMEF, fond 6, folder 3, unit 10, p. 35; MPAA, Zhytkavichy expedition 1999, fieldnotes 1, pp. 4, 8, 15, 25, 26, 30, 35, 44, 50; recordings by V.R. Shvaiko from 2000, fieldnotes 1, p. 6; Pashkova 1978: 71]. In the villages of the Pinsk and Stolin districts, respondents mention a special song ("Kalina" or "Bóbra"), which is performed by the bride after the first wedding night, but only if she had preserved her chastity until marriage [MBrDU, Stolin expedition 2001, fieldnotes 1, pp. 26-27; Stolin expedition 1997, 
fieldnotes 8 , p. 5, MPAA, recordings by V.R .Shvaiko, from 2000, fieldnotes 5-6, 14, 28]. In these villages people still remember the punishments that were formerly doled out to the bride's relatives, especially her parents, if the bride had lost her virginity before the wedding. The punishments included putting yokes around their necks and putting food into bowls with holes, among other practices [AIMEF, fond 7, folder 1, unit 879, pp. 32, 35a; MBrDU, Stolin expedition 1997, fieldnotes 8, p. 6; MPAA, Drahichyn expedition 2000, fieldnotes 1, p. 21, recordings by V.R. Shvaiko from 2000, fieldnotes 1, p. 6].

Another important stage of the wedding is the first visit of the young couple to the bride's parents and the reciprocal visit of the latter to the house of the newlyweds. This ritual is called hastsina or pirahi. A distinctive feature in the western areas, especially in the first half of the twentieth century, was the bride's parents' visit hastsina to the groom's parents' home. This took place on the Sunday following the visit of the newlyweds to the parents of the bride. Such a visit was considered mandatory. [AIMEF, fond 7, folder 1, unit 879, pp. 21a, 26; MPAZh, recordings in the village of Aniskavichy, Kobrin district, fieldnotes 4, p. 14].

One of the features of the western area is the absence of the custom of cross-dressing and also the absence of mock weddings and erotic games such as the game of rabbit described above. In the eastern part of Belarusian Palesse cross-dressing at the wedding is more extreme in nature [AIMEF, fond 7, folder 1 , unit 879, p. 34, fond 8 , folder 83 , unit 211, note 1, pp. 17, 84; MBrDU, Ivanava-Pinsk expedition 2000, fieldnotes 1, pp. 4, 31, 36, 40; Stolin expedition 1997, fieldnotes 8, p. 5; Ivanava expedition 1996, fieldnotes 4, p. 36, fieldnotes 5, p. 20; MPAA, Zhytkavichy expedition 1999, fieldnotes 1, pp. 4, 12; Drahichyn expedition 2000, fieldnotes 1, pp. 5, 8, 15, 17, 25, 38, 41, 46; records from 2003, fieldnotes 1, p. 7; Zakharava 1984: 278-279].

A distinctive feature of the West Palesse wedding is the gradual incorporation of the church ceremony into the structure of traditional rites. Respondents indicated that the church wedding was mandatory and had to take place on the first day of the wedding festivities. This is true in spite of the fact that church ritual was incorporated into the wedding only recently and that there is local variation in the incorporation of the church wedding into wedding rites. Thus, in some places the newlyweds arrive at the ceremony separately and meet only when they get to the church (village of Hrushava, Kobryn district. Some areas claim that this is especially true if the newlyweds were from different villages. This 
occurs in the villages of Matsiasy and Nalezniki of the Zhabinka district, the village of Bezdezh, Drahichyn district, the village of Dvorets, Zhytkavichy district, and the village of Haradnaia, Stolin district) [AIMEF, fond 8, folder 83, unit 210, fieldnotes 2, p. 29; MBrDU, Zhabinka expedition 1996, fieldnotes 2, p. 7, MPAA, Drahichyn expedition 2000, fieldnotes 1, p. 32; Iatskevich 2002: 483]. In most villages the groom picks the bride up before the wedding, and they go to church in the same "wedding train", but in separate cars. In this case, before the wedding the groom "bought" the bride from her bridesmaids (see the villages of Semuradtsy, Lenina, Liudzenevichy, Zhytkavichy district, the outskirts of Starobin, Salighorsk district, the villages of Svaryn' and Lipniki, Drahichyn district, and Mahro and Druzhilavichiy, Ivanava district) [MBrDU, Ivanava expedition 1996, fieldnotes 4, p. 4, fieldnotes 7, p. 8; MPAA, Zhytkavichy expedition 1999, fieldnotes 1, pp. 14, 38, 43, 45, 54; Zakharava 1984: 263]. According to another tradition, the payoff takes place after the wedding, when the groom returns to the bride's house after church for the purpose of taking her to his home (the village of Aniskavichy, Kobrin district, the village of Matsiasy, Zhabinka district, the villages of Vul'ka Simanavitskaia, Perkavichy, Khomsk, and Bezdzezh, Drahichyn district, the villages of Motal', Busa, Dastoeva, Vul'ka Dastoeuskaia, Klimentsinava, Ivanava district, Kazhan-Haradok, Luninets district, the villages of Plotnitsa, Hal'tsy, Berazhnoe, Stolin district, and Pahost, Zhytkavichy district) [AIMEF, fond 7, folder 1, unit 879, pp. 45, 49; MBrDU, Ivanava-Pinsk expedition 2000, fieldnotes 1, pp. 6, 22; Zhabinka expedition 1996, fieldnotes 2, p. 6; MPAA, Drahichyn expedition 2000, fieldnotes pp. 2, 16, 23, 36; recordings by V.R. Shvaiko from 2000, fieldnotes 1, pp. 3, 10; Kryvitski et al 1985: 354].

In sum, the East Palesse wedding complex is characterized by distinctive rites of separation. One of these is the "curling the tree" (vitstsie elki), a ritual where a special tree branch is decorated for the wedding festivities. A variant is the "curling" of the bride in her parents" house. This involves the ritual changing of the bride's headdress and is performed by special women called zavival'nitsy. The distinctive feature of East Palesse weddings is the mock wedding which follows the wedding proper, with its cross-dressing and its pronounced erotic element. In this area also the practice of eating chickens, sometimes "stolen" from wedding participants, is also characteristic and it has been well preserved into the present. In West Palesse the rites of separation take place during the evening for unmarried girls and also through the 
ritual of the pasad. The pasad in this area does not feature the act of putting on the married woman's headdress as a separate element in the ritual. It is also characteristic that, in this area, the pasad is performed in the home of the groom. Another feature found in West Palesse is the contest between the members of the groom's wedding party and the wedding party that comes from the side of the bride. The conflict between the two sides is most apparent at the point in the wedding when the bride is taken from her parents' home for the trip to the home of the groom. The opposition between the bride's side and that of the groom is far less pronounced in East Palesse.

The territory known as West Palesse in Belarusian ethnographic literature [Titov, 1983: 286-294; Tsitou: 145-149; Shamiakin 1989: 208], does in fact correspond with the area in which the West Palesse wedding complex is attested. The East Palesse wedding complex, however, does not fully coincide with certain geographical borders typically assigned to East Palesse [Titov, 1983: 279; Tsitou: 136-144; Shamiakin 1989: 507508]. At the time of this study, the local variants that were present on the territory of modern Petrykau, Lel'chytsy, and part of the Zhytkavichy district of Homel' region, exhibit mixed characteristics in which features of both East and West Palesse wedding complexes are combined.

\section{LIST OF ABBREVIATIONS}

1. AIMEF. АІМЭФ (Архіў інстытута Мастацтвазнаўства, этнаграфіі і фальклору імя К.Крапівы Нацыянальнай акадэміі навук Беларусі) - The Archive of the Institute of Study of Art, Ethnography and Folklore named after K. Krapiva.

2 MbRDU. МБрДУ (матэрыялы этнаграфічных экспедыцый выкладчыкаў i студэнтаў гістарычнага факультэта Брэсцкага дзяржаўнага універсітэта, Беларусь) - the materials of ethnographic expeditions of professors and students of the department of history at The Brest State University, Belarus.

3 MPAA. MПАА (матэрыялы 3 прыватнага архіву аўтаркі) the materials from the private archive of the author.

4 MПАЖ. MPAZh (матэрыялы 3 прыватнага архіву С.П. Жлобы, выкладчыка этналогіі Брэсцкага дзяржаўнага універсітэта, Беларусь) - the materials from the private archive of S.P. Zhloba, the lecturer of ethnology at The Brest State University, Belarus. 


\section{BIBLIOGRAPHY}

Baiburin, A. К. 1993. Байбурин, А. К. Ритуал в традиционной культуре: структурно-семантический анализ восточнославянских обрядов. [Ritual in Traditional Culture: StructuralSemantic Analysis of East European Customs]. Санкт-Петербург: Наука.

Bandarchyk, V. K. 1988. Бандарчык, В. К. Агульныя рысы $i$ рэгіянальныя асаблівасиі матэрыяльнай $і$ духоўнай культуры насельніцтва беларуска-уукраінскага Палесся. (Даклад на X Міжнародным з'ездзе славістаў) [Common Features and Local Peculiarities of Material and Spiritual Culture of Population of Ukrainian-Belarusian Palesse: The Report at the X International Congress of Slavists]. Мінск: Навука і тэхніка.

Bondarchik, V. К. et al. 1987. В. К. Бондарчик, Л. А. Боцонь, Л.И. Минько и др. Общественный, семейный быт и духовная культура населения Полесья [Social and Family Life and Spiritual Culture in Polesse]. Мінск: Наука и техника.

Davydiuk, V. 1997. Давидюк, В. "Полісько-Волинський народознавчий центр і його концепція досліження народної культури Полісся" [Polish - Volynia Folklore center and its Conception of Study Folk Culture in Polissia] Полісся. Етнікос, традиціï, культура. Луцьк: Вежа, 3-8.

Davydiuk, Z. 1997. Давидюк, 3. “Весільний сирний обряд Західного Полісся на археологічному тлі" [Wedding Cheese Ceremony in West Polissia from Archeological Perspective] Полісся. Етнікос, традииї, культура. Луцьк: Вежа, 239-247.

Dovnar-Zapol'skii, M. V. 1909. Довнар-Запольский М. В. Исследования и статьи. Этнография и сочиология, обычное право, статистика, белорусская письменность. [Studies and Articles. Ethnography and Sociology, Regular Law, Statistics, and Belarusian Writing]. Т. 1. Киев.

Fiadosik, A. S. 2000. Фядосік А. С. “Традыцыі ў народнай культуры Лоеушшчыны" [Traditions in Folk culture of Loeu District]. Памяиь.: Гісторыка-дакументальная хроніка Лоеўскага р-на /рэд. кал.: Г.П. Пашкоў (гал. рэд.) і інш. Мінск: БелЭН, 550-558.

Gura, A. В. 1981. Гура, А. В. “Опыт ареальной характеристики славянского свадебного обряда и его терминологии” [Study of Aerial Characteristic of Slavic Wedding Ritual and its 
Terminology]. Формирование раннефеодальных славянских народностей. Москва: Наука, 261-278.

Gura, A. B., et al. 1985. Гура, А. В., Терновская, О. А., Толстая, С. М. "Материалы к полесскому этнолингвистическому атласу" [Materials to Polesse Linguistic Atlas]. Полесский этнолингвистический сборник: материалы и исследования. Москва: Наука, 49-152.

Iatskevich, T. Dz. 2002. Яцкевіч T. Дз. "Традыцыйныя заняткі насельніцтва" [The Traditional Pursuits of Population]. Памяць: Гістарычна-дакументальная хроніка Кобрынскага раёна. Мінск: БЕЛТА, 477-492.

Jeleńska E. 1891. "Wieś Komarowicze w pow. Mozyrskim." [The Village Komarowicze in Mozyr District]. Wisła. T. V., 290-331; 479-590.

Kabashnikau, K. 1998. Кабашнікаў, К. "Вусная народная творчасць Нараўляншчыны" [Oral Folk Narratives of Narovlia People]. Памяџь: Гіст. - дакум. хроніка Нараўлянскага р-на. Мінск: БЕЛТА, 407-413.

Klimchuk, F. D. 1985. Климчук, Ф. Д. "Традиционная свадьба полесского села Симоновичи. Канун свадьбы. Венки” [Traditional Wedding of Polesse Village Simonovichi. Eve of the Wedding. Wreaths.] Полесский этнолингвистический сборник: материалы и исследования. Москва: Наука, 263-274.

Kryvitski, A. A. et al. (comp.) 1984. А. А. Крывіцкі, Г. А. Цыхун, І. Я. Яшкін. Тураўскі слоўнік (Т.3) . [The Turau Dictionary (Vol. 3)]. У 5-ці т. Мінск: Навука і тэхніка.

Kryvitski, A. A. et al. (comp.) 1985. А. А. Крывіцкі, Г. А. Цыхун, І. Я. Яшкін. Тураусскі слоуннік. (Т.4) [The Turau Dictionary (Vol 4)]. У 5-ці т. Мінск: Навука і тэхніка.

Kryvitski, A. A. et al. (comp.) 1987. А. А. Крывіцкі, Г. А. Цыхун, І. Я. Яшкін і інш. Тураўскі слоўнік. (Т.5) [The Turau Dictionary (Vol 5)]. У 5-ці т. Мінск: Навука і тэхніка.

Moszyński, K. 1928. Polesie Wschodnie: Materjały etnograficzne ze wschodniej części powiatu mozyrskiego oraz z powiatu rzeczyckego. [Eastern Polesie: Ethnographic Materials from Eastern Part of Mozyr' District of Rechitsa Region]. Warszawa: Wydawnictwo kasy im. Mianowskiego.

Novak, V. S. 1998. Новак, В. С. "Народная творчасць Гомельскага рна" [Folk Art in Homel District] Памяцьь.: Гісторыка- 
дакументальная хроніка Гомельскага р-на. У 2-х кн. Кн. 2. Мінск: БЕЛТА, 345-360.

Pashkova, G. T. 1978. Пашкова, Г. Т. Етнокультурні зг̃язки украӥнщів та білорусів Полісся. На матеріалах весільної обрядовості. [Ethnic-Cultural Relations of Belarusians and Ukrainians of Polisse. According to the Materials of Wedding Rituals]. Київ: Наукова думка.

Ritual Folklore. 1998. Абрадавы фальклор гомельскага Палесся. [Ritual Folklore of Homel Palesse]. Гомель: Гомельскі цэнтр навукова-тэхнічнай і дзелавой інфармацыі.

Shamiakin, I. P. (ed.). 1989. Шамякін, I. П. (гал. рэд.). Этнаграфія Беларусі: Эниьлкапедыя [Ethnography of Belarus: Encyclopedia]. Мінск: БелСэ.

Shein, P. V. 1902. Шейн П. В. Материалы для изучения быта и языка русского населения Северо-западного края. [Materials for Study of Everyday Life and Language of Russian Population of NorthernWestern Region] T. 3. Санкт-Петербург.

Shteiner, F. and V. S. Novak (comps.). 2002. Штэйнер, Ф., Новак, В. C. (уклад.) Фальклорна-этнаграфічная $і$ літаратурная спадчына Рэчыцкага раёна. [Folkloric-Ethnographic Heritage of Rechytsa District]. Мінск: Неман.

Tarashkevich, P. I. (comp.) 1992. Тарашкевіч, Р. I. (уклад.) Святы $i$ абрады Берасиейшчыны [Holidays and Rituals of Brest Region]. Мінск: Беларус. ін-т праблем культуры, Берасц. навук.-метад. цэнтр культуры.

Titov, V. S. 1983. Титов, В. С. Историко-этнографическое районирование материальной культуры белорусов. ХIX начало XX вв. [Historical-Ethnographical Zoning of Material culture of Belrausians. $19^{\text {th }}$ - early $20^{\text {th }}$ centuries]. Мінск: Наука и техника.

Tsitou, V. S. 1994. Цітоў В. С. Народная спадчына: матэрыяльная культура $\check{y}$ лакальна-тыпалагічнай разнастайнасці [Folk Heritage: Material Culture in Local Diversity]. Мінск: Навука i тэхніка.

Tsiv'ian, T. V. 1983. Цивьян Т. В. “Анализ одного полесского текста в связи с мифологемой сада" [Analysis of One Polesse Text in Relation to the Myth of Garden]. Полесье $и$ этногенез славян: Предварительные материаль и тезисы конференции. Москва: Наука, 96-98. 
Tsvirka, К. (ed. and comp.) 2004. К. Цвірка (уклад., уступны арт. і камент.) Вяселле: Абрад. [Wedding: Ritual]. Мінск: Беларуская навука.

Zakharava, V. A. (ed. and comp.). 1984. Захарава, В. А. (уклад. і рэд.) Палескае вяселле. [Palesse Wedding]. Мінск: Універсітэцкае.

Translated by Hanna Chuchvaha 